\title{
Battle against Aging and Folds: Benefit and Risks of the Semi-Permanent Fillers Polylactic Acid and Calcium Hydroxylapatite
}

\author{
Elisabeth Hanf*, Ursula Gresser \\ Ludwig-Maximilians University of Munich, Munich, Germany \\ Email: elisabeth.hanf@gmx.de
}

Received 1 April 2014; revised 1 May 2014; accepted 14 May 2014

Copyright (C) 2014 by authors and Scientific Research Publishing Inc. This work is licensed under the Creative Commons Attribution International License (CC BY). http://creativecommons.org/licenses/by/4.0/

(c) (;) Open Access

\begin{abstract}
Background: Semi-permanent fillers are among the most favorable fillers on the market. Through their unique mode of action and its associated lasting aesthetic effect, they take an exceptional position. Objective: To compare the two semi-permanent fillers Poly-L-Lactic Acid (PLLA) and calcium hydroxylapatite (CaHA) in reference to the aesthetic result, patient satisfaction and side effects. Methods: Studies on side effects, patient satisfaction and aesthetic results after augmentation with semi-permanent fillers were analyzed. Results: Semi-permanent fillers seem excellently suited for the augmentation of very deep wrinkles particularly in the lower half of the face. In general, high patient satisfaction can be determined with both fillers. Here, the effect from the polylactic acid can be verified for up to two years while no effect could be verified already after one year in a majority of the patients augmented with CaHA. Short-term side effects such as bleedings or erythema in the region of the augmented area have been observed in both fillers during augmentation. The incidence of nodules and granulomas seems significantly higher in augmentations with PLLA compared to CaHA. Rare side effects such as an embolization of a blood vessel caused by the implant have been described for both fillers in case reports. Conclusion: Semi-permanent fillers are superbly suited for wrinkle augmentation. Which filler is the preferred one in what case depends strongly on the individual needs of the patient and the therapist's experience.
\end{abstract}

\section{Keywords}

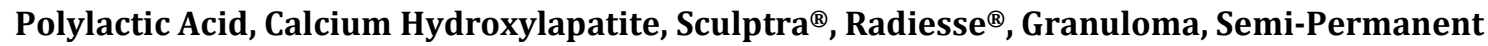
Fillers

\footnotetext{
${ }^{*}$ Corresponding author.
}

How to cite this paper: Hanf, E. and Gresser, U. (2014) Battle against Aging and Folds: Benefit and Risks of the Semi-Permanent Fillers Polylactic Acid and Calcium Hydroxylapatite. Advances in Aging Research, 3, 130-141. 


\section{Introduction}

The increasing interest in youthful appearance of the aging "Baby-Boomer" generation combined with the beauty ideal staged by the media, increases the market for aesthetic interventions accordingly [1]. Only a few decades ago, the effect of gravity has been thought of being the main culprit for the aging of the face [2]. Today, it is known that the aged appearance of the face is the result of complex extrinsic and intrinsic processes. Therefore, the dermal formation of wrinkles is explained by the unavoidable loss of collagen and extra-cellular fiber matrix and by the atrophy of the dermis and epidermis [3].

The increasing loss of subcutaneous fat tissue and the successive loss of sub-dermal collagen lets the lower half of the face appear increasingly concave [4]. Therefore, one of the main objectives in the augmentation of the face is the restoration of the convexity of all dermal structures [5].

Accordingly, the absolute number of wrinkle augmentation treatments has increased in the United States (US) by 205\% plus from 2000 to 2011 [6]. According to reports, anti-wrinkle treatments with injections of lipids have already been carried out during the 19th century [7]. Since that time, the range of implantable filler products has increased steadily. Since its launch in 1981, bovine collagen (e.g. Zyderm ${ }^{\circledR}$ ) has been the filler, which was the most frequently used filler for wrinkle augmentation for more than ten years [7] [8]. One negative aspect of bovine collagen is the potential for causing allergic reactions because of the foreign proteins, which requires a twostage skin test prior to the actual treatment [8]. Due to its significant side-effect profile, bovine collagen was swiftly replaced by modern fillers [6].

Permanent fillers such as silicones (e.g. Silicon ${ }^{\circledR}$ ) were also used to augment wrinkles. However, studies demonstrated that silicone is the cause of an increased occurrence of auto-immune reactions and it has even a certain carcinogenic potential in addition to the development of late granulomas [9]. The annual report of the American Society of Plastic Surgeons shows that hyaluronic acid (e.g. Restylane ${ }^{\circledR}$ ) with its 1.4 million applications has been the most frequently used temporary, substance in the United States in 2011 [6]. Hyaluronic acid (HA) has a low allergenic potential and a good safety profile. On the other hand, it has a relatively short half-life of approx. three months [10].

Semi-permanent Fillers: Semi-permant Fillers are defined by the duration of their effect which can be more than 18 months but it is never permanent [11]. With 277,346 and 139,038 applications respectively, semi-permanent fillers such as calcium hydroxylapatite (e.g. Radiesse ${ }^{\circledR}$ ) or polylactic acid (e.g. Newfill ${ }^{\circledR}$; e.g. Sculptra ${ }^{\circledR}$ ) have been the second and third most frequently applied fillers in the United States in 2011 [6].

The Ideal Filler: Currently, there are approx. 160 different fillers available worldwide [12]. All differ in their modes of action, half-lives and substance-specific side effect profile. In this context, Lemperle has described the properties of perfect filler: the ideal filler is biocompatible, safe in its application and it remains permanently at the location of the injection. Volume and suppleness remain permanently consistent. The ideal filler causes a minimum foreign body reaction. The implant has no potential to migrate to other places and moreover, it does not cause any granulomas [13]. So far, there hasn't been any filler that combines all of these characteristics.

\section{Material and Methods}

A comprehensive literature research was required for this work. Studies were examined, which dealt with the aesthetic results, side effects, and patient satisfaction of these fillers. For this purpose, the following search engines were utilized: Google, Google Scholar, PubMed, Medline and OPAC plus of the Bavarian State Library in Munich. Additional original works were located in the source references of these studies. Employees of Merz and Sinclair Pharma were kind enough to provide information about prices, application, and regulations. Only publications written in German or English were included. Overall, 55 sources could be used. The selected literature was analyzed, summarized, and in part illustrated in form of tables. The literature was obtained through the Bavarian State Library in Munich and inter-library loan services of the Bavarian State Library in Munich.

\section{Results}

\subsection{Poly-L-lactic Acid}

Since PLLA has been first synthesized by French chemists in 1954, it is applied in many areas of modern medicine [17] PLLA has been used for years as component of self-absorbing surgical sutures and as carrier for timerelease pharmaceuticals [4] [16] Another field of application for PLLA is the augmentation of tissue defects or 
unevenness of the body caused by the human immunodeficiency virus (HIV). In the facial region, PLLA is used for augmentation and particular for the augmentation of larger defects in the lower facial half such as the nasolabial fold (NLF), marionette lines, mentolabial folds, cheeks, and the pre-jowl sulcus. In addition, some therapists use PLLA as filler for the temporal region and the periorbital area [19].

\subsubsection{PLLA Application and Implantation Technique}

The manufacturer recommends suspending the dry PLLA substance in $5 \mathrm{~mL}$ sterile water for at least two hours prior to the planned implantation. According to the manufacturer's information, the maximum number of treatments for one region is four sessions [19]. It is recommended to use a 26 gauge (G) needle for implantation. It is ideally injected into the subcutis. For the even distribution of the implant, the treated area should be massaged directly after implantation and over the next five days five times daily for five minutes according to the $5 \times 5 \times 5$ rule [19]. Table 1 shows the PLLA application and injection techniques applied in the studies.

\subsubsection{Patient Satisfaction with PLLA}

Patient satisfaction with the aesthetic result of an augmentation treatment with PLLA was surveyed in numerous studies. $79 \%$ of patients (90 patients) treated by Fabi und Goldman, stated that they would undergo augmentation treatment with PLLA again. For $17 \%$ of the patients, the treatment costs, the degree of aesthetic result and the pain associated with the augmentation were the main reasons why they would not undergo another treatment. The remaining $3 \%$ were undecided [20].

In the patient group (221 patients) treated by Lowe, $72 \%$ of patients stated that they would undergo the same treatment again. Another 14\% were undecided, while the remaining 14\% rejected another therapy [23]. The patient evaluation (10 patients) of Salles et al. shows that three months after the augmentation, $80 \%$ of patients were dissatisfied or very dissatisfied with the aesthetic result. Another three months later, $60 \%$ of the patients stated that they were very satisfied or satisfied with the aesthetic results. After 36 months, $60 \%$ of patients found the result satisfactory or very satisfactory. $30 \%$ of patients were dissatisfied, while the remaining $10 \%$ were highly dissatisfied with the aesthetic result [26]. In the study published by Vleggaar (2131 patients), 95.1\% of treated patients stated that the expected result has been achieved or exceeded by the treatment, while $4.9 \%$ were dissatisfied with the result [14].

In the patient survey (130 patients) undertaken by Palm et al., 68\% of patients stated that they would undergo another treatment, while 33\% would not have another augmentation with PLLA and another $12 \%$ were undecided [22].

Table 1. PLLA application and injection techniques applied in the studies.

\begin{tabular}{|c|c|c|c|c|c|}
\hline Author & Pat.(n) & Implantation & $\begin{array}{l}\text { Suspension } \\
\text { time }\end{array}$ & Touch up(n) & $\begin{array}{l}\text { Follow-up } \\
\text { treatment }\end{array}$ \\
\hline $\begin{array}{l}\text { Fabi, Goldman } \\
\text { 2012 [20] }\end{array}$ & $\mathrm{n}=90$ & $\begin{array}{l}\text { PLLA in } 8 \mathrm{ml} \text { ( } 7 \mathrm{ml} \text { aqua, } 1 \mathrm{ml} \text { lidocaine }{ }^{\circledR} \text {, } \\
1: 100.000 \text { epinephrine) }\end{array}$ & $>2 \mathrm{~h}$ & $1-5$ & $\begin{array}{l}5 \times 5 \times 5 \\
\text { (Massage ) }\end{array}$ \\
\hline $\begin{array}{l}\text { Narins et al. } \\
2010[21]\end{array}$ & $\mathrm{n}=116$ & PLLA in $5 \mathrm{ml}$ aqua & $2 \mathrm{~h}$ & Up to 4 & $\begin{array}{l}\text { Massage after } \\
\text { implantation }\end{array}$ \\
\hline $\begin{array}{l}\text { Vleggaar } \\
2006[14]\end{array}$ & $\mathrm{n}=2131$ & PLLA in $5 \mathrm{ml}$ ( $4 \mathrm{ml}$ aqua, $1 \mathrm{ml}$ lidocaine ${ }^{\circledR}$ ) & $24 \mathrm{~h}$ & $0-5$ & $\begin{array}{l}5 \text { minutes massage } \\
\text { daily for } 2 \text { weeks }\end{array}$ \\
\hline $\begin{array}{l}\text { Palm et al. } \\
2010 \text { [22] }\end{array}$ & $\mathrm{n}=130$ & $\begin{array}{l}\text { PLLA in 6-11 ml (5 - } 10 \mathrm{ml} \text { aqua, } 1 \mathrm{ml} \text { lidocaine }{ }^{\circledR} \text {, } \\
\text { 1:100.000 epinephrine) }\end{array}$ & $24 \mathrm{~h}$ & $0-5$ & $\begin{array}{l}\text { Massage for } \\
\text { one week }\end{array}$ \\
\hline $\begin{array}{l}\text { Lowe et al. } \\
2009 \text { [23] }\end{array}$ & $\mathrm{n}=221$ & PLLA in $5 \mathrm{ml}$ (4 ml aqua, $1 \mathrm{ml}$ xylocaine $\left.{ }^{\circledR}\right)$ & $4 \mathrm{~h}$ & $0-4$ & $\begin{array}{l}\text { Massage after } \\
\text { implantation }\end{array}$ \\
\hline $\begin{array}{l}\text { Schierle, Casas } \\
2011[24]\end{array}$ & $\mathrm{n}=106$ & $\begin{array}{l}\text { PLLA in } 8 \text { - } 10 \mathrm{ml}(6 \mathrm{ml} \text { aqua, } 2 \text { - } 4 \mathrm{ml} \\
\left.\text { lidocaine }^{\circledR} 2 \%\right)\end{array}$ & $48 \mathrm{~h}$ & $0-8$ & $\begin{array}{l}\text { Massage after } \\
\text { implantation }\end{array}$ \\
\hline $\begin{array}{l}\text { Woerle et al. } \\
2004 \text { [16] }\end{array}$ & $\mathrm{n}=300$ & $\begin{array}{l}\text { PLLA in } 3 \mathrm{ml} \text { aqua } \\
\text { PLLA in } 5 \mathrm{ml} \text { ( } 3 \mathrm{ml} \text { aqua, } 2 \mathrm{ml} \text { lidocaine }{ }^{\circledR} \text { ) }\end{array}$ & $\begin{array}{l}2-12 \mathrm{~h} \\
36-4 \mathrm{~h}\end{array}$ & Not specified & $\begin{array}{l}\text { Massage after } \\
\text { implantation, } \\
\text { cooling }\end{array}$ \\
\hline $\begin{array}{l}\text { Daines, Williams } \\
2013 \text { [25] }\end{array}$ & $\mathrm{n}=811$ & PLLA in $8 \mathrm{ml}$ aqua & $48 \mathrm{~h}$ & Not specified & Not specified \\
\hline
\end{tabular}




\subsubsection{Expert Evaluation of PLLA}

Narins assessed the success of therapy with the Lemperle rating scale (LRS). The current findings were compared to the initial findings at different times [21] [27]. Table 2 shows the results that were achieved over time. In this study, 116 patients with the desire of augmentation were included in the NLF. The initial depth of the wrinkles varied in all patients from LRS 2 to LRS 4 . Salles et al. have surveyed the therapy success after augmentation of NLF with PLLA six and 36 months after the first session. The results of this study are shown in Table 3.

\subsubsection{Side Effects of PLLA}

With regard to the side effects of an augmentation treatment with semi-permanent fillers, a differentiation has to be made between primary and secondary side effects. Table 4 shows the side effects observed in the analyzed studies Primary side effects are nearly always self-limited and a direct consequence of the implantation. Secondary side effects such as the formation of papules and granuloma occur frequently weeks or years after an augmentation treatment.

Table 2. Change in the LRS over time after PLLA treatment.

\begin{tabular}{cccccccc}
\hline Month & 1 & 3 & 6 & 9 & 13 & 19 & 25 \\
\hline Change in LRS & -0.66 & -0.7 & -0.73 & -0.73 & -0.85 & -0.77 & -0.72 \\
\hline
\end{tabular}

Narins, et al. 2010 [21].

Table 3. Therapy success after augmentation of NLF with PLLA six and 36 months after the first session.

\begin{tabular}{ccc}
\hline & 6 months & 36 months \\
\hline Totally successful & $50 \%$ & $10 \%$ \\
Successful & $30 \%$ & $0 \%$ \\
Somewhat successful & $20 \%$ & $30 \%$ \\
No change & $0 \%$ & $60 \%$ \\
\hline
\end{tabular}

Salles et al. 2008 [26].

Table 4. Side effects observed after PLLA treatment.

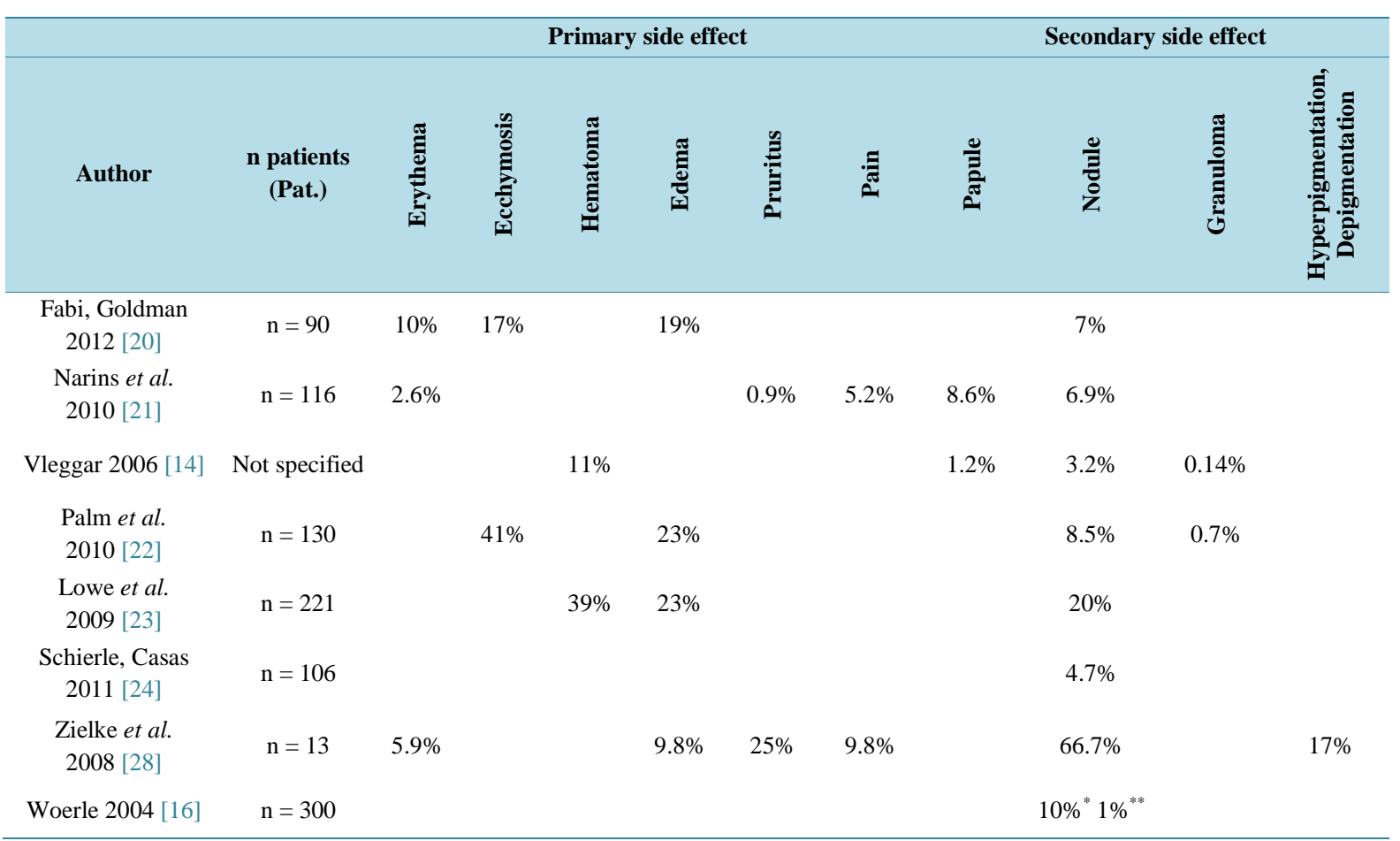

* Suspension $2 \mathrm{~h}$ prior to implantation in $3 \mathrm{~mL}$ aqua; ${ }^{* *}$ Suspension in $5 \mathrm{~mL}$ ( $3 \mathrm{~mL}$ aqua, $2 \mathrm{~mL}$ lidocaine) 36 - $48 \mathrm{~h}$ prior implantation. 


\subsubsection{Therapy Nodules and Granuloma Formation after PLLA Treatment}

So far, there is no clear therapy regiment to treat nodules or granuloma caused by a PLLA implant. The therapy approaches used by the therapists can be seen in Table 5 .

\subsubsection{Rare Side Effects of PLLA}

Because PLLA is supposed to be implanted into the subcutis, there is the risk of occlusion of a blood vessel or other anatomic structures. In this context, one case of a 67-year-old patient published by Nichols et al. should be mentioned. Six months after a PLLA augmentation treatment of the cheeks, painfully swollen nodules developed in the region of the patient's right cheek. During the physical examinations, it was not possible to exprimate any secretion from the right parotid duct. Through additional radiological examinations, it was determined that the right parotid duct was compressed by the PLLA implant, which leads to a parotitis as secondary side effect. Through persistent massage of the affected region, it was possible to relieve the compression of the parotid duct caused by the implant [33].

Another recently published report describes a case of acute blindness after the PLLA augmentation HIV-positive patient suffering from orbital lipodystrophy [34]. In this case, the PLLA was accidentally injected into the arterial vessel system of the optic nerve, which lead to direct blindness and ophthalmoplegia of the affected eye [34].

\subsection{Calcium Hydroxylapatite}

In the United States, calcium hydroxylapatite (CaHA) has been approved for wrinkle augmentation in 2006 [7] [35]. According to the manufacturer, since its approval more than two million CaHA treatments have been carried out worldwide from 2004 to 2010 [36]. CaHA is a natural component of the inorganic bone and tooth substance [37].

One unit of CaHA consists of a suspension of small calcium hydroxylapatite microspheres (30\%) ranging in diameter between 25 - $45 \mu \mathrm{m}$. These are suspended in a gel carrier (70\%), hydrophilic carboxymethyl cellulose, glycerin and sterile water [35] [38] [39]. The hydrophilic carrier gel is absorbed by the body—what remains are the microspheres, which work like a sort of support for incoming Fibroblasts produce native collagen, which is the true cause for the filling effect [35] Calcium hydroxylapatite is degraded to calcium and phosphate [37] [40].

In addition to the augmentation of wrinkles in the face, CaHA is also used in many other areas of aesthetic and traditional medicine. Since 2002, CaHA is approved for the augmentation of vocal cords as a symptomatic therapy for unilateral or bilateral vocal cord paresis [35]. In addition, it serves as radiological tissue marker because it has a low level of radiolucency [7]. As natural component of the inorganic bone and tooth substance, calcium hydroxylapatite is also used for the augmentation of osseous or dental substance defects [41]. Larger calcium hydroxide particles (75 - $175 \mu \mathrm{m})$ serve as filler to treat the symptoms of stress incontinence [12] [43]. Other aesthetic indications for CaHA are the reconstruction of the nipple, to balance contour effects after liposuction or for severe acne vulgaris [9] [11]. In addition, CaHA is used to lift the tip of the nose within the frame-

Table 5. Therapy approaches to treat side effects after PLLA treatment.

\begin{tabular}{|c|c|c|c|c|c|c|}
\hline Author & Side effect & $\begin{array}{c}\text { Intralesional } \\
\text { steroid injection }\end{array}$ & Laser & Excision & $\begin{array}{c}\text { Imiquimod }^{\circledR} \\
\text { topical }\end{array}$ & No therapy \\
\hline Narins et al. 2010 [21] & Nodules, papules & $\mathrm{x}(1)$ & & & & $\mathrm{x}$ \\
\hline Palm et al. 2010 [22] & Granuloma & & & $\mathrm{x}(1)$ & & \\
\hline Lowe et al. 2009 [23] & Nodules, papules & $\mathrm{x}$ & & $x(2)$ & & $x(5)$ \\
\hline Schierle, Casas 2011 [24] & Nodules, papules & & & $\mathrm{x}(1)$ & & $x(4)$ \\
\hline Woerle 2004 [16] & Nodules, papules & $\mathrm{x}$ & & & & \\
\hline Beer 2009 [29] & Nodules, papules & $\mathrm{x}(2)$ & & $\mathrm{x}$ & & \\
\hline Beljaards et al. 2005 [4] & Nodules, papules & $\mathrm{x}$ & & $\mathrm{x}$ & $\mathrm{x}$ & \\
\hline Hamilton et al. 2008 [30] & Nodules, papules & $\mathrm{x}$ & & & & \\
\hline Oppel et al. 2003 [31] & Nodules, papules & $\mathrm{x}$ & & & & \\
\hline Cassuto et al. 2009 [32] & Granuloma & & $\mathrm{x}$ & & & \\
\hline
\end{tabular}


work of non-surgical rhinoplasty [40]. Finally, CaHA is also applied to even out visually lipoatrophy caused by such diseases as advanced HIV [44].

\subsubsection{CaHA Application and Implantation Technique}

Preparation: CaHA is available in ready-to-use syringes of various sizes $(0.3 \mathrm{ml} ; 0.8 \mathrm{ml}$ and $1.5 \mathrm{ml})$ [36]. Since 2009, CaHA is available on the American market in combination with $2 \mathrm{ml}$ of $2 \%$ lidocaine HCL as Radiesse- $L^{\circledR}$ [36] [45]. It is recommended to mix the substances at least 2 hours prior to implantation [36]. The manufacturer recommends the use of a 27 or 28 gauge needle included in the system for implantation [36]. The needle should penetrate the skin in an angle of 30 degrees and then, it should be inserted to the subcutis. As soon as this layer is reached, the parallel implantation strings should be placed in accordance with a retrograde implantation [36]. To achieve an even distribution of the implant, it is recommended to massage the treated area after implantation [36]. Table 6 summarizes the CaHA application and implantation techniques applied in the analyzed studies.

The manufacturer does not give any statements as to the maximum number of touch-up treatments or the time interval between individual sessions.

\subsubsection{Patient Satisfaction with CaHA}

Patient satisfaction with the aesthetic result of an augmentation treatment with CaHA was surveyed in numerous studies. 28 of the patients treated by Fakhre et al. assessed their satisfaction at different times on the Likert scale. The scale ranges from 1 (dissatisfied) to 5 (highly satisfied) One to seven weeks after implantation, the average satisfaction was 3.7. One year following the implantation, the aesthetic result was still assessed at 2.3. 71\% of the surveyed patients would recommend the product to a friend [4].

In the patient group (16 patients) surveyed by Grunebaum et al., the average satisfaction at the time of the survey was over 4.5 [45]. The patient group (82 patients) treated by Roy et al., assessed the aesthetic result three and six months after the implantation with an average score of 4.6 [46]. From the patient group of Sadick et al., 41 of 113 treated patients valued the aesthetic result three months after implantation with 4.6 and six months after implantation with 4.8 [47].

From the total of 609 patients treated by Jansen and Graivier, 155 participated in the survey six months following the implantation and 112 participated in the survey after 12 - 24 months [9]. Six months after implantation, 89\% of the surveyed patients stated that they would undergo another treatment [9]. 12 - 24 months after the augmentation treatment, $69 \%$ of the patients stated that they are satisfied with the result, $24 \%$ were dissatisfied with the result, whereby the main reason was the short duration of the esthetic effect [9].

\subsubsection{Expert Evaluation of CaHA}

The therapists used the global aesthetic improvement score (GAIS) [38] in addition to the LRS [27] in order to assess the degree of aesthetic result. Table 7 summarizes the results of the expert evaluation after an augmenta-

\begin{tabular}{|c|c|c|c|c|}
\hline Author & Pat.(n) & Implantation & Touch up(n)Interval & Follow-up treatments \\
\hline $\begin{array}{l}\text { Roy et al. } \\
2006[46]\end{array}$ & $\mathrm{n}=90$ & $\begin{array}{l}27 \text { G CaHA + lidocaine in lip augmentation } \\
\text { otherwise without lidocaine }\end{array}$ & 1 touch up; interval: 6 months & No information \\
\hline $\begin{array}{l}\text { Jacovella et al. } \\
\quad 2005[41]\end{array}$ & $\mathrm{n}=50$ & CaHA & none & No information \\
\hline $\begin{array}{l}\text { Smith et al. } \\
2007 \text { [38] }\end{array}$ & $\mathrm{n}=117$ & $\begin{array}{l}\text { Anesthesia: Nerve block, lidocaine cream, } \\
27 \mathrm{G}\end{array}$ & max. 2; interval: 2 weeks & $\begin{array}{l}\text { Massage and cooling after } \\
\text { treatment }\end{array}$ \\
\hline $\begin{array}{l}\text { Jansen, Gravier } \\
2006 \text { [9] }\end{array}$ & $\mathrm{n}=609$ & $\begin{array}{l}\text { CaHA + } 1 \text { ml lidocaine 0.5\%, 1:100.000 } \\
\text { epinephrine) } 27 \text { G }\end{array}$ & $\begin{array}{l}0 \text { - } 1 \text { touch up Interval: } 4 \text { - } 9 \\
\text { weeks }\end{array}$ & $\begin{array}{l}\text { Cooling and massage for } \\
\text { one week }\end{array}$ \\
\hline $\begin{array}{l}\text { Sadick et al. } \\
2007[47]\end{array}$ & $\mathrm{n}=113$ & $\begin{array}{l}\text { CaHA + lidocaine 1\%, 1:100.000 } \\
\text { epinephrine, } 27 \mathrm{G}\end{array}$ & $\begin{array}{l}0 \text { - } 1 \text { touch-up treatment Interval: } \\
\text { no information }\end{array}$ & No information \\
\hline $\begin{array}{l}\text { Marmur et al. } \\
2009 \text { [48] }\end{array}$ & $\mathrm{n}=100$ & CaHA in part + lidocaine, 27 G & $\max .1$ & Massage after implantation \\
\hline $\begin{array}{l}\text { Moers Carpi } \\
2007 \text { [39] }\end{array}$ & $n=205$ & CaHA, $27 \mathrm{G}$ & max 1 Interval: 4 months & no information \\
\hline
\end{tabular}


Table 7. Expert Evaluation of CaHA.

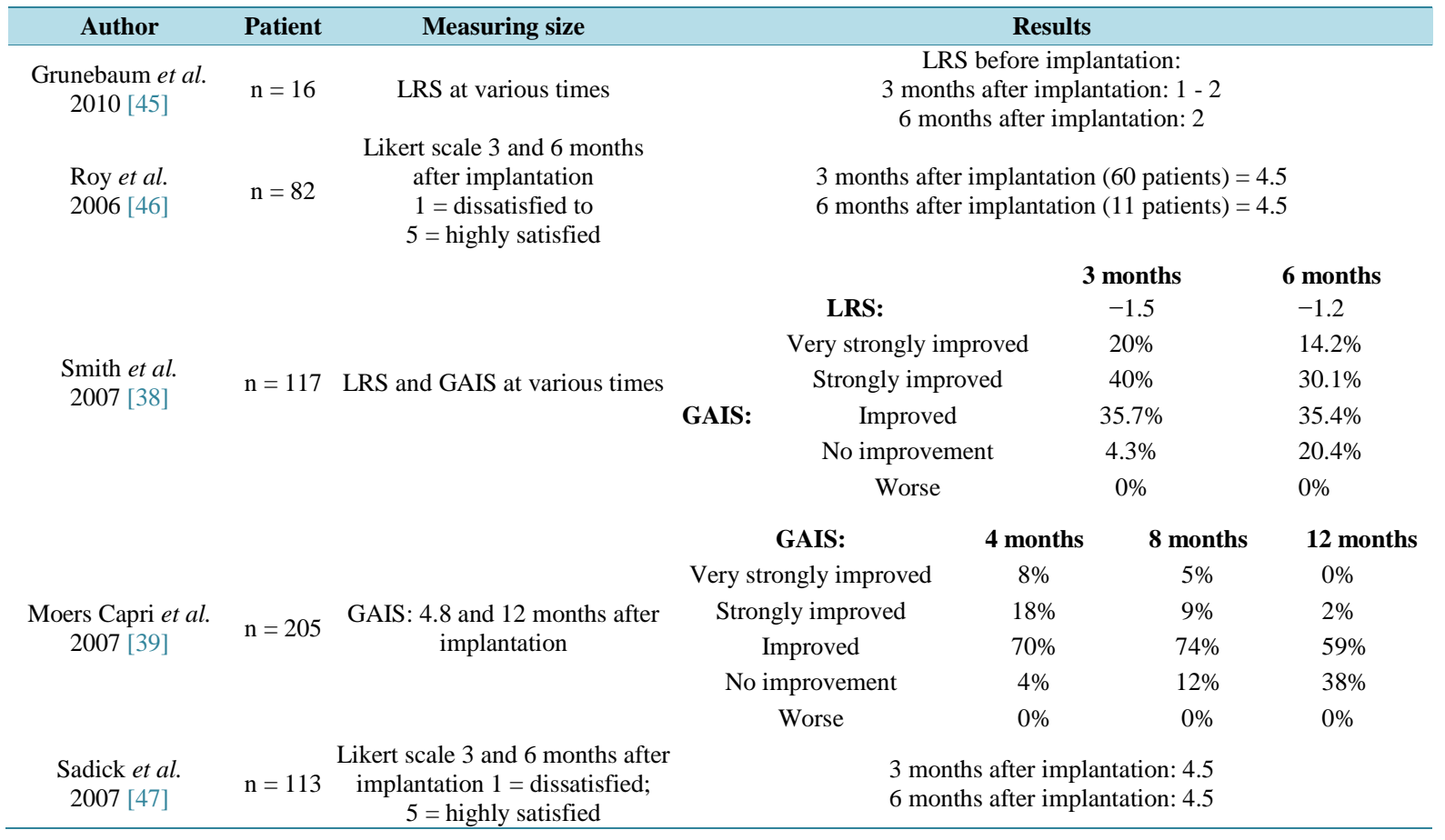

tion treatment with CaHA.

\subsubsection{Side Effects of CaHA}

Table 8 provides an overview of the documented side effects in the reviewed studies.

\subsubsection{Therapy Nodules and Granuloma Formation after CaHA Treatment}

There is also not a clear regimen for the treatment of nodules and granuloma following an augmentation treatment with CaHA. In a large portion of the studies, steroids were applied into the lesion [9] [46] [47]. In another portion, the nodules were either removed surgically with a needle or by skin incision [25] [37].

\subsubsection{Rare Side Effects of CaHA}

Because of the deep implantation, there is the risk of an embolization of a blood vessel by the implant. In one case published by Tracy et al., a 41-year-old patient had following a CaHA augmentation of the melolabial fold initially a change in color of the left nostril and later a tissue necrosis caused by the occlusion of the blood supplying vessel [50].

\subsection{Comparison of the Most Important Characteristics}

An overview of the most important characteristics of both fillers is given in Table 9.

\section{Summary}

\section{Can semi-permanent fillers be compared based on the current study or data situation?}

Despite the similar modes of action of PLLA and CaHA, there is currently no study, which compares these fillers. However, based on the comprehensive data situation, both substances can be compared. Overall, more than 3500 patients received PLLA treatment and more than 2600 patients were treated with CaHA in these studies. The follow-up periods, which are available, are up to 36 months for both substances.

Because the studies showed significant differences in terms of sizes, implantation techniques, time of the survey, it must be considered in the review of the results and it must be seen as limitation with regard to the assessment of these results. 
Table 8. Side effects of CaHA.

\begin{tabular}{|c|c|c|c|c|c|c|c|c|c|c|c|}
\hline & & \multicolumn{6}{|c|}{ Primary side effects } & \multicolumn{4}{|c|}{ Secondary side effects } \\
\hline Author & n (Pat) & 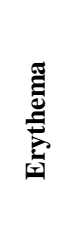 & 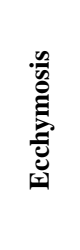 & 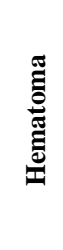 & 䔍 & 莣 & 青 & 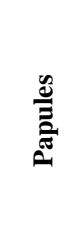 & $\begin{array}{l}\text { 菅 } \\
\text { ż }\end{array}$ & 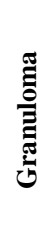 & 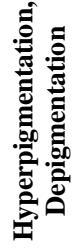 \\
\hline $\begin{array}{c}\text { Jacovella et al. } \\
2005[41]\end{array}$ & $\mathrm{n}=50$ & & $5 \%$ & & & & & & & & \\
\hline $\begin{array}{l}\text { Smith et al. } \\
2007 \text { [38] }\end{array}$ & $\mathrm{n}=117$ & $70 \%$ & $63 \%$ & & $73 \%$ & $18 \%$ & $29 \%$ & $8.6 \%$ & $0.9 \%$ & & \\
\hline $\begin{array}{l}\text { Marmur } 2010 \text { (without } \\
\text { lidocaine) [49] }\end{array}$ & $\mathrm{n}=50$ & $64 \%$ & $50 \%$ & & $88 \%$ & $32 \%$ & $50 \%$ & & & & \\
\hline $\begin{array}{l}\text { Marmur } 2010 \text { (with } \\
\text { lidocaine) [49] }\end{array}$ & $\mathrm{n}=130$ & $58 \%$ & $52 \%$ & & $94 \%$ & $26 \%$ & $44 \%$ & & & & \\
\hline $\begin{array}{l}\text { Sadick et al. } \\
2007 \text { [47] }\end{array}$ & $\mathrm{n}=113$ & & $3 \%$ & & $2 \%$ & & & & $2 \%{ }^{*}$ & & \\
\hline $\begin{array}{l}\text { Daines, Williams } \\
2012 \text { [25] }\end{array}$ & $\mathrm{n}=231$ & & & & $1 \%$ & & & & $0.4 \%$ & & \\
\hline
\end{tabular}

*Formation of nodules exclusively after augmentation of lips.

Table 9. Important characteristics of PLLA and CaHA.

\begin{tabular}{|c|c|c|}
\hline & PLLA [4]-[6] [14]-[16] [19] [21]-[24] [27] [29]-[34] [52] & $\begin{array}{l}\text { CaHA [6] [7] [18] [25] [35]-[38] [40] [41] [47 } \\
{[49]-[53]}\end{array}$ \\
\hline Approved in Europe & 1999 & 2004 \\
\hline Approved in the & 2004 & 2006 \\
\hline Applications in the US (2012) & 139,038 & 277,346 \\
\hline $\begin{array}{l}\text { Treatments (manufacturer's } \\
\text { information) }\end{array}$ & 1 - 4 sessions per area & no response \\
\hline Unit & $2 \times 150 \mathrm{mg}$ dry substance, sterile water & $0.3 ; 0.5$ and $1 ; 5 \mathrm{~mL}$ in disposable syringes \\
\hline Areas & $\begin{array}{l}\text { NLF } \\
\text { Cheeks } \\
\text { Peritoneal region } \\
\text { Dark circles under the eyes } \\
\text { Marionette lines } \\
\text { Temporal region } \\
\text { Upper lip } \\
\text { Chin } \\
\text { Mentolabial fold }\end{array}$ & $\begin{array}{l}\text { NLF } \\
\text { Cheeks } \\
\text { Peritoneal region } \\
\text { Dark circles under the eyes } \\
\text { Marionette lines } \\
\text { Temporal region } \\
\text { Mentolabial fold } \\
\text { Corner of the mouth } \\
\text { Glabella line }\end{array}$ \\
\hline Layer of the skin & Subcutis & Subcutis \\
\hline Degradation & $\begin{array}{l}\text { Hydrolysis, Red-ox reaction to Co2 and acetyl coenzyme } \\
\text { A or oxalacetate }\end{array}$ & Degradation to calcium and phosphate \\
\hline Modes of action & $\begin{array}{l}\text { induction of foreign body reaction, new collagen } \\
\text { formation }\end{array}$ & Fibroblast stimulation, new collagen formation \\
\hline $\begin{array}{l}\text { Preparation (manufacturer's } \\
\text { information) }\end{array}$ & $\begin{array}{l}\text { Suspension in } 5 \mathrm{ml} \text { sterile water at least } 2 \text { hours prior to } \\
\text { the planned injection }\end{array}$ & Pre-filled syringe \\
\hline $\begin{array}{l}\text { Duration of the effect } \\
\text { (Manufacturer's information) }\end{array}$ & $>24$ months & $>12$ months \\
\hline $\begin{array}{l}\text { Side effects, distribution in } \\
\text { percentage }\end{array}$ & $\begin{array}{l}3905 \text { patients, } 1267 \text { side effects: } \\
65 \% \text { nodules, papules } \\
20 \% \text { erythema } \\
13 \% \text { bleeding, ecchymosis } \\
2 \% \text { others }\end{array}$ & $\begin{array}{l}2675 \text { patients, } 801 \text { side effects: } \\
32 \% \text { nodules, papules } \\
23 \% \text { edemas; swellings } \\
18 \% \text { erythema } \\
16 \% \text { bleeding, ecchymosis } \\
8 \% \text { pain } \\
3 \% \text { others }\end{array}$ \\
\hline Rare (case reports) & $\begin{array}{l}\text { multifocal abscesses } \\
\text { Parotitis } \\
\text { Loss of vision after arterial embolism }\end{array}$ & $\begin{array}{l}\text { Necrosis of the treated area } \\
\text { Tissue necrosis of the nostril } \\
\text { Herpes zoster after augmentation }\end{array}$ \\
\hline
\end{tabular}


Do these semi-permanent fillers meet the purpose in the area of wrinkle augmentation as promised by the manufacturer?

According to the study results, both semi-permanent fillers are superbly suited for augmentation of very deep wrinkles, particularly in the area of the lower half of the face. However, in direct comparison, with PLLA the result can only be noticed after several weeks but the aesthetic result lasts significantly longer. In contrast, the aesthetic result of CaHA is immediately visible but it does not last as long.

How do the semi-permanent fillers differ in their preparation and implantation? What substances are more user-friendly?

As opposed to CaHA, which comes in pre-filled syringes, PLLA must be suspended in water prior to the planned implantation. Because a biofilm surrounding the implant may be the possible cause for the later formation of granuloma, the preparation process of PLLA may be a potential source of bacterial contamination. During the implantation of CaHA, no such prior preparation of the filler is required, which can be seen as a significant advantage of CaHA compared to PLLA.

What consequences can be expected in augmentations with semi-permanent fillers and how often do these occur?

When injecting semi-permanent fillers into wrinkles, both CaHA and PLLA have the risk of primary and secondary side effects. Primary side effects such as bleeding and swelling in the area of the injection are nearly unavoidable and occur with both fillers equally. To reduce the sense of pain, the filler can be injected in combination with a synthetic analgesic, which leads to a significant reduction in pain.

Therefore, it should be pointed out that each of these modifications is connected with direct consequences. Example local anesthetics: Through the additional application of synthetic local anesthetics, the patient will feel less pain during and after the implantation. Because the local anesthetic has a vessel relaxing effect, the bleeding risk is increased [54]. To minimize this risk the therapist can apply additional vasoconstricting substances. The use of vasoconstricting substances has the risk that when the implant causes ischemia for example through embolization of a blood vessel, it is recognized too late or not at all [54].

Arterial embolization caused by the filler with subsequent necroses of the under-supplied area is one of the most feared but very rare primary side effects. To minimize this risk, it is recommended to carry out an aspiration prior to the implantation. It is essential for the therapist to have an in-depth anatomical knowledge about the area to be augmented and to have the possibility to treat such embolization. The most frequent secondary side effect that occurs particularly if PLLA is used for augmentation is the formation of nodules or granuloma in the area of the augmented region. It is specifically noted that the percentage of these complications can be significantly reduced through longer suspension times and a greater dilution. In addition, if patients use nicotine, which poses a significant risk factor for the formation of granuloma and papules [52] [54] [55]. Accordingly, PLLA should not be used for augmentation in this patient group. Granuloma and nodules are also observed in augmentations with CaHA; however, the percentage is significantly lower. An exception is the significantly higher incident of granuloma and papules after CaHA is used for lip augmentation. Therefore, CaHA is no longer recommended for the augmentation of lips.

So far, there is no clear therapy regimen for the treatment of such nodules or granuloma. In addition to the steroid application, surgical excision is successful. Because both measures carry a certain risk, it remains to be said at this point that in some studies, granuloma and nodules resolved itself after some time but without further treatment.

\section{Conclusion}

Through their long lasting aesthetic result and the high patient satisfaction, semi-permanent fillers take a special position and the aesthetic wrinkle treatment can no longer be thought of without them. According to the results, the choice of suitable semi-permanent filler depends significantly on the individual needs of the patient. If it is important for the patient to achieve a swift improvement, which may potentially decrease after a few months, then CaHA is the preferred substance. If the patient prefers a rather gradual change visible only after a few months following the first session, then PLLA would be the first choice based on its slow effect. However, this treatment is still not without risk, of which the therapist and the patient should be aware. In this connection, Lemperle talks about the so-called "learning curve": the shorter the time the implant remains, the larger the probability for technical areas to occur during the injection [42]. Conversely it means that the implantation of 
such lasting fillers requires profound knowledge of the therapist and extensive information of the patient about any potential risks. This is the absolute prerequisite for a satisfactory result.

\section{Acknowledgements}

This review is based on the thesis of Elisabeth Hanf "Vergleich der semipermanenten Füllstoffe Kalziumhydroxylapatit und Polymilchsäure. Wirkungen, Nebenwirkungen Ästhetisches Ergebnis, Patientenzufriedenheit, Gesetzeslage in Deutschland” at the Medical Faculty of the Ludwig-Maximilians University Munich.

\section{References}

[1] Goldman, M.P. (2011) Cosmetic Use of Poly-l-Lactic Acid. My Technique for Success and Minimizing Complications. Dermatologic Surgery, 37, 688-693. http://dx.doi.org/10.1111/j.1524-4725.2011.01975.X

[2] Lam, S.M., Azizzadeh, B. and Graivier, M. (2006) Injectable Poly-L-Lactic Acid (Sculptra): Technical Considerations in Soft-Tissue Contouring. Plastic and Reconstructive Surgery, 118, 55-63. http://dx.doi.org/10.1097/01.prs.0000234612.20611.5a

[3] Schneider, L.A., Wlaschek, M. and Scharffetter-Kochaneck, K. (2003) Hautalterung-Klinik und Pathogenese. Journal der Deutschen Dermatologischen Gesellschaft, 3, 223-232. http://dx.doi.org/10.1046/j.1610-0387.2003.03515.x

[4] Beljaards, R.C., Roos, K.P. and Bruins, F.G. (2005) New Fill for Skin Augmentation: A New Filler or Failure? Dermatologic Surgery, 31, 772-776. http://dx.doi.org/10.1111/j.1524-4725.2005.31709

[5] Bauer, U. and Graivier, M.H. (2011) Optimizing Injectable Poly-L-Lactic Acid Administration for Soft Tissue Augmentation: The Rationale for Three Treatment Sessions. Canadian Journal of Plastic Surgery, 19, 22-27.

[6] American Society of Plastic Surgeons (2013) Plastic Surgery Statistics Report. http://www.plasticsurgery.org/Documents/news-resources/statistics/2012-Plastic-Surgery-Statistics/full-plastic-surgery -statistics-report.pdf

[7] Fakhre, G.P., Perdikis, G., Shaddix, K.K., Terkonda, S.P. and Waldorf, J.C. (2009) An Evaluation of Calcium Hydroxylapatite (Radiesse) for Cosmetic Nasolabial Fold Correction: A Meta-Analysis and Patient Centric Outcomes Study. Annals of Plastic Surgery, 63, 486-489. http://dx.doi.org/10.1097/SAP.0b013e31819516ec

[8] Alam, M., Gladstone, H., Kramer, E.M., Murphy, J.P., Nouri, K., Neuhaus, I.M., Spencer, J.M., Spenceri, E., Van Dyke, S., Ceilley, R.I., Lee, K.K., Menaker, G., Monheit, G.D., Orentreich, D.S., Raab, B. and Smith, K.C. (2008) ASDS Guidelines of Care: Injectable Fillers. Dermatologic Surgery, 34, 115-148. http://dx.doi.org/10.1111/j.1524-4725.2008.34253.x

[9] Jansen, D.A. and Graivier, M.H. (2006) Evaluation of a Calcium Hydroxylapatite-Based Implant (Radiesse) for Facial Soft-Tissue Augmentation. Plastic and Reconstructive Surgery, 118, 22-30. http://dx.doi.org/10.1097/01.prs.0000234903.55310.6a

[10] De Lorenzi, C. (2013) Complications of Injectable Fillers, Part I. Aesthetic Surgery Journal, 33, 561-575. http://dx.doi.org/10.1177/1090820X13484492

[11] Cohen, J.L. (2008) Understanding, Avoiding and Managing Dermal Filler Complications. Dermatologic Surgery, 34, 92-99. http://dx.doi.org/10.1111/j.1524-4725.2008.34249.x

[12] Funt, D. and Pavicic, T. (2013) Dermal Fillers in Aesthetics: An Overview of Adverse Events and Treatment Approaches. Clinical, Cosmetic and Investigational Dermatology, 6, 295-316.

[13] Lemperle, G., Morhenn, V. and Charrier, U. (2003) Human Histology and Persistence of Various Injectable Filler Substances for Soft Tissue Augmentation. Aesthetic Plastic Surgery, 27, 354-366. http://dx.doi.org/10.1007/s00266-003-3022-1

[14] Vleggaar, D. (2006) Soft-Tissue Augmentation and the Role of Poly-L-Lactic Acid. Plastic and Reconstructive Surgery, 118, 46-54. http://dx.doi.org/10.1097/01.prs.0000234846.00139.74

[15] Bolton, J., Fabi, S., Peterson, J. and Goldmann, M. (2011) Poly-L-Lactic Acid for Chest Rejuvenation: A Retrospective Study of 28 Cases Using a 5-Point Chest Wrinkle Scale. Cosmetic Dermatology, 24, 278-284.

[16] Woerle, B., Hanke, W. and Sattler, G. (2004) Poly-L-Lactic Acid: A Temporary Filler for Soft Tissue Augmentation. Journal of Drugs in Dermatology, 3, 385-389.

[17] Broder, K.W. and Cohen, S.R. (2006) An Overview of Permanent and Semipermanent Fillers. Plastic and Reconstructive Surgery, 118, 7S-14S. http://dx.doi.org/10.1097/01.prs.0000234900.26676.0b

[18] Koolmann, J. and Röhm, K.H. (1994) Gewebe und Organe, Kalzium P. 386 ff. Taschenatlas der Biochemie. Stuttgart Thieme.

[19] Sanofi Aventis, SCULPTRA ${ }^{\circledR}$ Aesthetic (2012) Injectable Poly-L-Lactic Acid. Package Insert, Bridgewater. 
http://www.sculptraaesthetic.com/sculptra_aesthetic.pdf

[20] Fabi, S.G. and Goldman, M.P. (2012) The Safety and Efficacy of Combining Poly-L-Lactic Acid with Intense Pulsed Light in Facial Rejuvenation: A Retrospective Study of 90 Patients. Dermatologic Surgery, 38, 1208-1216.

[21] Narins, R.S., Baumann, L., Brandt, F.S., Fagien, S., Glazer, S., Lowe, N.J., Monheit, G.D., Rendon, M.I. Rohrich, R.J. and Werschler, P. (2010) A Randomized Study of the Efficacy and Safety of Injectable Poly-L-Lactic Acid versus Human-Based Collagen Implant in the Treatment of Nasolabial Fold Wrinkles. Journal of the American Academy of Dermatology, 62, 448-462. http://dx.doi.org/10.1016/j.jaad.2009.07.040

[22] Palm, M.D., Woodhall, K.E., Butterwick, K.J. and Goldman, M.P. (2010) Cosmetic Use of Poly-L-Lactic Acid: A Retrospective Study of 130 Patients. Dermatologic Surgery, 36, 161-170. http://dx.doi.org/10.1111/j.1524-4725.2009.01419.x

[23] Lowe, N.J., Maxwell, C.A., Lowe, P., Shah, A. and Patnaik, R. (2009) Injectable Poly-L-Lactic Acid: 3 Years of Aesthetic Experience. Dermatologic Surgery, 35, 344-349. http://dx.doi.org/10.1111/j.1524-4725.2008.01061.x

[24] Schierle, C.F. and Casas, L.A. (2011) Nonsurgical Rejuvenation of the Aging Face with Injectable Poly-L-Lactic Acid for Restoration of Soft Tissue Volume. Aesthetic Surgery Journal, 31, 95-109. http://dx.doi.org/10.1177/1090820X10391213

[25] Daines, S.M. and Williams, E.F. (2013) Complications Associated with Injectable Soft-Tissue Fillers. A 5-Year Retrospective Review. JAMA Facial Plastic Surgery, 15, 226-231. http://dx.doi.org/10.1001/jamafacial.2013.798

[26] Salles, A.G., Lotierzo, P.H., Gimenez, R., Camargo, C.P. and Ferreira, M.C. (2008) Evaluation of the Poly-L-Lactic Acid Implant for Treatment of the Nasolabial Fold: 3-Year Follow-Up Evaluation. Aesthetic Plastic Surgery, 32, 753756. http://dx.doi.org/10.1007/s00266-008-9182-2

[27] Lemperle, G., Holmes, S., Cohen, S.R. and Lemperle, S. (2001) A Classification of Facial Wrinkles. Plastic and Reconstructive Surgery, 108, 1735-1750.

[28] Zielke, H., Wölber, L., Wiest, L. and Rzany, B. (2008) Risk Profiles of Different Injectable Fillers: Results from the Injectable Filler Safety Study (IFS Study). Dermatologic Surgery, 34, 326-335. http://dx.doi.org/10.1111/j.1524-4725.2007.34066.x

[29] Beer, K.A. (2009) Clinicopathologic Correlation of Delayed-Onset Periorbital Poly-L-Lactic Acid Nodules Dermatologic Surgery, 35, 399-402. http://dx.doi.org/10.1111/j.1524-4725.2008.01043.x

[30] Hamilton, D., Gauthier, N., Robertson, B.F. and Late-Onset, (2008) Late-Onset, Recurrent Facial Nodules Associated with Injection of Poly-l-lactic Acid. Dermatologic Surgery, 34, 123-126. http://dx.doi.org/10.1111/j.1524-4725.2007.34027.x

[31] Oppel, T., Schaller, M., Flaig, M. and Korting, H.C. (2003) Fremdkörpergranulome nach dermaler Injektion eines auf Polymilchsäure basierenden Implantates zur Behandlung von Falten. Journal der Deutschen Dermatologischen Gesellschaft, 3, 220-222.

[32] Cassuto, D., Marangoni, O., De Santis, G. and Christensen, L. (2009) Advanced Laser Techniques for Filler-Induced Complications. Dermatologic Surgery, 35, 1689-1695. http://dx.doi.org/10.1111/j.1524-4725.2009.01348.x

[33] Nichols, B.J., Carpenter, J., Hribar, K.P., Go, J. and Rice, D.H. (2011) Acute Parotitis after Injection of Poly-L-Lactic Acid for Malar Augmentation: A Case Report and Review of Relevant Anatomy. Dermatologic Surgery, 37, 381-386. http://dx.doi.org/10.1111/j.1524-4725.2011.01892.x

[34] Robert, S.A.I. and Arthurs, B.P. (2012) Severe Visual Loss and Orbital Infarction Following Periorbital Aesthetic Poly-(L)-Lactic Acid (PLLA) Injection. Ophthalmic Plastic \& Reconstructive Surgery, 28, e68-e70.

[35] Daley, T., Damm, D., Haden, J.A. and Kolodychak, M.T. (2012) Oral Lesions Associated with Injected Hydroxyapatite Cosmetic Filler. Oral Surgery, Oral Medicine, Oral Pathology, Oral Radiology, 114, 107-111. http://dx.doi.org/10.1016/j.oooo.2012.03.012

[36] Merz North America (2013) RADIESSE. Injectable Implant Instructions for Use. http://www.radiesse.com/RADIESSE Wrinkle Filler Instructions for Use.pdf

[37] Tzikas, L.T. (2008) A 52-Month Summary of Results Using Calcium Hydroxylapatite for Facial Soft Tissue Augmentation. Dermatologic Surgery, 34, S9-S15. http://dx.doi.org/10.1111/j.1524-4725.2008.34237.x

[38] Smith, S., Busso, M., McClaren, M.K. and Bass, L.S. (2007) A Randomized, Bilateral, Prospective Comparison of Calcium Hydroxylapatite Microspheres versus Human-Based Collagen for the Correction of Nasolabial Folds. Dermatologic Surgery, 33, S112-S121. http://dx.doi.org/10.1111/j.1524-4725.2007.33350.X

[39] Moers-Carpi, M., Vogt, S., Santos, B.M., Planas, J., Vallve, S.R. and Howell, D.J. (2007) A Multicenter, Randomized Trial Comparing Calcium Hydroxylapatite to Two Hyaluronic Acids for Treatment of Nasolabial Folds. Dermatologic Surgery, 33, S144-S151. http://dx.doi.org/10.1111/j.1524-4725.2007.33354.X

[40] Bitar, G.J., Osunsade, O. and Devabhaktuni, A. (2012) Injection/Filler Rhinoplasty. Aesthetic Medicine. In: Erian, A. 
and Shiffman, M.A., Eds., Advanced Surgical Facial Rejuvenation, Springer Berlin Heidelberg, Berlin, 625-639.

[41] Jacovella, P., Peiretti, C.B., Cunille, D., Salzamendi, M. and Schechtel, S.A. (2006) Long-Lasting Results with Hydroxylapatite (Radiesse) Facial Filler. Plastic and Reconstructive Surgery, 118, 15S-21S. http://dx.doi.org/10.1097/01.prs.0000234902.61284.c9

[42] Lemperle, G., Gauthier-Hazan, N. and Wolters, M. (2006) Komplikationen nach Faltenunterspritzung und ihre Behandlung. Handchirurgie, Mikrochirurgie, Plastische Chirurgie, 38, 354-369. http://dx.doi.org/10.1055/s-2006-955889

[43] Alam, M., Havey, J., Pace, N.B.S., Pongprutthipan, M. and Yoo, S. (2011) Large-Particle Calcium Hydroxylapatite Injection for Correction of Facial Wrinkles and Depressions. Dermatologic Surgery, 65, 92-96.

[44] Comite, S., Greene, A., Cieszynski, S.A., Zaroovabeli, P. and Marks, K. (2007) Minimizing Discomfort during the Injection of Radiesse with the Use of Either Local Anesthetic or Ice. Dermatology Online Journal, 13, 5.

[45] Grunebaum, L.D., Elsaie, M.L. and Kaufmann, J. (2010) Six-Month, Double-Blind, Randomized, Split-Face Study to Compare the Efficacy and Safety of Calcium Hydroxylapatite (CaHA) Mixed with Lidocaine and CaHA Alone for Correction of Nasolabial Fold Wrinkles. Dermatologic Surgery, 36, 760-765. http://dx.doi.org/10.1111/j.1524-4725.2010.01555.x

[46] Roy, D., Sadick, N. and Managat, D. (2006) Clinical Trial of a Novel Filler Material for Soft Tissue Augmentation of the Face Containing Synthetic Calcium Hydroxylapatite Microspheres. Dermatologic Surgery, 32, 1134-1139. http://dx.doi.org/10.1111/j.1524-4725.2006.32256.x

[47] Sadick, N., Katz, B. and Deborshi, R. (2007) A Multicenter, 47-Month Study of Safety and Efficacy of Calcium Hydroxylapatite for Soft Tissue Augmentation of Nasolabial Folds and Other Areas of the Face. Dermatologic Surgery, 33, S122-S127. http://dx.doi.org/10.1111/j.1524-4725.2007.33351.x

[48] Marmur, E.S., Taylor, S.C., Grimes, P.E., Boyd, C.M., Porter, J.P. and Yoo, J.Y. (2009) Six-Month Safety Results of Calcium Hydroxylapatite for Treatment of Nasolabial Folds in Fitzpatrick Skin Types IV to VI. Dermatologic Surgery, 35, 1641-1645. http://dx.doi.org/10.1111/j.1524-4725.2009.01311.x

[49] Marmur, E.S., Green, L. and Busso, M. (2010) Controlled, Randomized Study of Pain Levels in SubjectsTreated with Calcium Hydroxylapatite Premixed with Lidocainefor Correction of Nasolabial Folds Dermatologic Surgery, 36, 309315

[50] Tracy, L., Ridgway, J., Nelson, J.S., Lowe, N. and Wong, B. (2013) Calcium Hydroxylapatite Associated Softtissue Necrosis: A Case Report and Treatment Guideline. Journal of Plastic, Reconstructive \& Aesthetic Surgery, 67, 564568

[51] Merz Aesthetic der V Effect (2010) Der V-Effekt Volumenaufbau für jugendliche Formgebung Arztfolder. Hg. v. Merz Ästhetics. Frankfurt.

[52] Goldan, O., Garbov-Nardini, G., Regev, E., Orenstein, A. and Winkler, E. (2008) Late-Onset Infections and Granuloma Formation after Facial Polylactic Acid (New-Fill) Injections in Women Who Are Heavy Smokers. Plastic and Reconstructive Surgery, 121, 336e-338e.

[53] Sires, B., LauKaitis, S. and Whitehouse, P. (2008) Radiesse-Induced Herpes Zoster. Ophthalmic Plastic and Reconstructive Surgery, 24, 218-219. http://dx.doi.org/10.1097/IOP.0b013e31816d9565

[54] Aktories, K., Förrstermann, U., Hofmann, F., Starke, K. and Biel, M. (2008) Allgemeine und spezielle Pharmakologie und Toxikologie. Kapitel 8 Lokalanästhetika, 245-251. 10. Aufl., Urban \& Fischer, München.

[55] Rossner, F. (2010) Unerwünschte Wirkungen auf ein injiziertes Polymilchsäurepräparat Ergebnisse der Injectable Filler Safety-Studie. Dissertation, Charité Universitätsmedizin Berlin, Berlin.

\section{List of Abbreviations}

CaHA: Calcium Hydroxylapatite

G: Gauge

GAIS: Global Aesthetic Improvement Score

HIV: Human Immunodeficiency Virus

LRS: Lemperle Raiting Scale

NLF: Nasolabial Fold

Pat.: Patients

PLLA: Poly-L-Lactic Acid

US: United States 